\title{
CONTRIBUTION TO RESEARCH OF THERMAL LOADS IN COMMERCIAL VEHICLES POWERTRAIN MOUNTS
}

\author{
Miroslav D. Demića ${ }^{\text {, Jasna D. Glišović }}$ \\ University of Kragujevac, Faculty of Engineering, \\ Department for motor vehicles and motors, \\ Kragujevac, Republic of Serbia, \\ a e-mail: demic@kg.ac.rs, \\ ORCID iD: - $h t t p: / / o r c i d . o r g / 0000-0003-2168-1370$, \\ be-mail: jaca@kg.ac.rs, \\ ORCID iD: @http://orcid.org/0000-0002-8251-1722
}

http://dx.doi.org/10.5937/vojtehg65-14028

\begin{abstract}
FIELD: Mechanical Engineering, Motor Vehicles and Motors
ARTICLE TYPE: Original Scientific Paper

ARTICLE LANGUAGE: English
\end{abstract}

\begin{abstract}
:
Due to the effects of excitations of road micro-roughness and the powertrain as well as due to the conditions of movement (acceleration, braking, curvilinear movement), the weights of commercial vehicles perform complex spatial oscillations. The negative impact of these movements or dynamic loads caused by them and transmitted to the supporting system of the vehicle can be reduced by a proper selection of the position and characteristics of the powertrain mounts. Elastic and damping forces in mounts perform mechanical work that turns into heat energy. Theoretical, experimental and combined methods can be used for the analysis of thermal loads of mounts. In this paper, research was carried out with theoretical methods using a mechanical model of the powertrain. Vibrations were observed on a freight vehicle powertrain of FAP 1314 middle-class vehicles. Bearing in mind the presence of classical (rubbermetal) and hydraulic mounts in modern commercial vehicles, the authors analysed the thermal loads of the mentioned vehicle type using a mathematical model.
\end{abstract}

Key words: excitation, commercial vehicles, mounts, modeling, powertrain, heat.

ACKNOWLEDGMENT: The authors are grateful for the financial support of TR35041 Project named The research of vehicle safety as part of a cybernetic system: Driver-Vehicle-Environment funded by the Ministry of Science and Technological Development of the Republic of Serbia. 


\section{Introduction}

The powertrain vibrations are transmitted over the mounts to the vehicle frame, while noise is transferred to the vehicle frame (structural) through the environment (air) as well. In order to reduce this effect to a satisfactory measure, the powertrain is elastically bound to the vehicle carrier system. At the same time, this system absorbs vibration excitations which are transferred to the powertrain from the road surface through the vehicle suspension system. Due to the kinetic energy of the powertrain resulting from vibrations, mechanical work is converted to heat in the mounts (Mitschke \& Wallentowitz, 2004).

In practice, the characteristics of the powertrain system are chosen from the conditions of minimizing noise and vibration. The task can be solved using analytical (theoretical) methods, using mathematical models, or experimentally. The progress of computer technology has contributed to greater application of mathematical models, while experimental methods, due to high costs, are rarely used. In doing so, the thermal loads which powertrain mounts are exposed to are usually ignored, which, in cases of poorly solved heat removal, can cause distortion of mount characteristics. Therefore, it is considered appropriate to analyze their thermal loads.

Research has shown that mechanical work due to powertrain vibrations turns into heat energy that is transmitted, in a wider sense, to the environment (Bojić, 2011), (llić et al, 1996), (Moran, 2010), (Fermi, 2011), (Demić \& Diligenski, 2016), (Mitschke \& Wallentowitz, 2004):

$$
A=Q_{t}+Q_{f}+Q_{o},
$$

where $A$ is a mechanical operation (equivalent to the amount of heat), J; $Q_{\mathrm{t}}$ part of the heat surrendering to the mount body, J; $Q_{\mathrm{f}}$ part of the heat surrendering to the fluid (for hydraulic mounts), J; and $Q_{0}$ part of the heat surrendering to the environment, J.

The work of elastic and damping forces in mounts is important for the analysis of heat loads, and it can be measured and experimentally measured (Mitschke \& Wallentowitz, 2004) with more difficulty. Due to the distribution of heat inside the mount, as well as around it, the problem becomes significantly more complex.

It is noted that most of the heat is transferred by convection (the phenomenon that occurs when the fluid convection material exchanges heat within itself). A slightly smaller part of the heat is transferred by conduction (molecules of solids that vibrate at a higher temperature vibrate more rapidly over the equilibrium position and in collision with molecules having a lower temperature cause an energy impulse that accelerates the vibrations of these molecules and increases the temperature) and radiation 
(occurs between any two objects at different temperatures, whether vacuum is between them or not) (Bojić, 2011), (Mitschke \& Wallentowitz, 2004).

Converting mechanical work into heat largely depends on the construction of mounts. Therefore, during the design of the powertrain system, consideration should be given to creating the conditions for the good transfer of heat to the environment. It should be noted that the aim of this paper is not to investigate the transfer of heat to the environment from powertrain mounts, but to determine the amount of heat generated by vibrations in mounts.

As it is known, classic mounts consist of rubber-metal elements, with a dampening of the hysteresis of the tire, while hydraulic mounts have additional damping due to oil which they contain. Bearing in mind the presence of classical (rubber-metal) and hydraulic mounts in modern freight vehicles, the authors analysed the thermal loads of a FAP 1314 vehicle.

Motor vehicles represent complex oscillation systems with a large number of masses of interconnected elasto-damping elements, of most often non-linear characteristics. When traveling on uneven roads, the exitations from road roughness are transferred through the wheels and the elastic suspension system to the frame and further on to the powertrain (through the powertrain suspension system). In addition, the drive unit additionally oscillates the movable mass of the vehicle. The negative impact of vibrations on the characteristics of motor vehicles can be reduced by a correct selection of the position and characteristics of the elastodamping elements. This can be done using theoretical-experimental, theoretical or experimental methods (Frolov \& Furman, 1990).

In the literature (Demić, 1990), (Demić, 1997a), (Demić, 1997b), (Demić, 2002), (Demić, 2013), (Simić, 1988), (Simić \& Demić, 1992), (Bendat, 1998), (Igami et al, 2008), (Genta, 2003), (Shanguan et al, 2016) there are a number of mathematical-experimental methods for modeling the behavior of the powertrain. In this paper, a freight vehicle from the FAP 1314 production program, (whose scheme of the suspension of the powertrain is shown in Figure 1) was observed and the modeling process was applied based on the principles of classical mechanics (Atkins, 2010), (Pars, 1981).

The aim of the research is to begin theoretical analyzes of the problem of thermal loads of powertrain mounts, and the verification of the obtained results will be performed at a later stage in experimental research. It is expected that the results obtained will be used in designing new vehicles from the FAP production program.

\section{Model of a powertrain}

Depending on the task being worked out, various mechanical models of powertrains and vehicles can be found. From (Demić, 1990), (Demić, 
1997), (Rotenberg, 1972), (Genta, 2003), (Gillespie, 1992), (Milliken \& Milliken, 1995), (Simić \& Demić, 1992), (Kennings et al, 2014), (Shanguanet al, 2016), it is known that during the analysis of the problem of transferring dynamic loads from the powertrain to the frame (chassis) of the vehicle, the oscillations of the cabin and the carriage compartment can be ignored. More precisely, the analysis includes only the oscillatory movements of the powertrain of the vehicle and the corresponding exitations from the vehicle frame.

The structure of the vehicle model and the powertrain should therefore be chosen to enable the analysis of the desired parameters. This indicates the need to use as simple mathematical models as possible, because due to the absence of precise inertial and geometric parameters of the powertrain and the vehicle itself, as well as the characteristics of the mounts, more complex models can lead to major errors (Demić, 1990), (Frolov \& Furman, 1990).

The powertrain, as a rigid body in space, has six degrees of freedom (three translations and three rotations), so, to describe its movement, it is necessary to use six independent generalized coordinates (Demić, 1990), (Frolov \& Furman, 1990), (Genta, 2003), (Pars, 1981), (Gillespie, 1992), (Milliken \& Milliken, 1995). Here are adopted geometric gravity axes for observing the movement of the powertrains, starting at an equilibrium position, which will be discussed later. It is worth mentioning that the use of the geometric gravity axis leads to the need of using centrifugal moments of inertia, but, for the sake of the ease of analysis, the assumption that they are also the principal axes of inertia is introduced. The powertrain performs spatial vibrations under the action of excitations it receives from the frame (originating from the road roughness, vibrations of the frame as an elastic system, inertial forces of braking, inertial force of acceleration, centrifugal forces in curvilinear movement and Coriolis forces due to the complex movement of the vehicle), as well as from the inertial forces and torque of the engine and the rotating masses.

Six generalized coordinates should be introduced to describe the spatial movement of the powertrain: three translations and three rotations (Demić, 1990), (Frolov \& Furman, 1990), (Genta, 2003), (Pars, 1981), (Gillespie, 1992), (Milliken \& Milliken, 1995). Two coordinate systems will be adopted (Demić, 1990), Figure 2:

- immobile (OXYZ), with the origin at the center of gravity of the powertrain (defined in relation to its equilibrium position). The axes of this system coincide with the geometric axes of the powertrain symmetry (it is at the same time the global coordinate system),

- movable $(C \xi \eta \zeta)$, which is firmly attached to the powertrain and rotates with it. The transformation of the coordinate system from $(C \xi \eta \zeta)$ to (OXYZ) and vice versa can be made using three independent angles (Euler angles - which lead to coupled differential equations), or angles of rolling, galloping and winding that lead to a 
scattered system of differential equations. Since the model used had only one angle- the rotation around the $X$ axis for the angle $\varphi$, it was not necessary to use three angles.

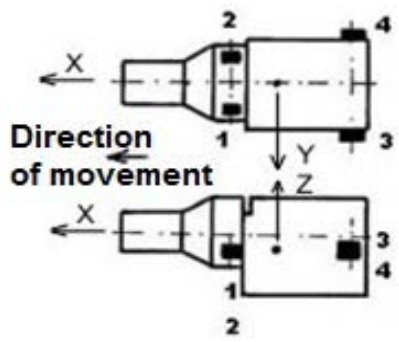

Figure 1 - Scheme of the powertrain mounts of a freight motor vehicle

Puc. 1 - Схема опоры силового привода грузового автомобиля

Слика 1 - Шема ослањања погонске групе посматраног теретног моторног возила

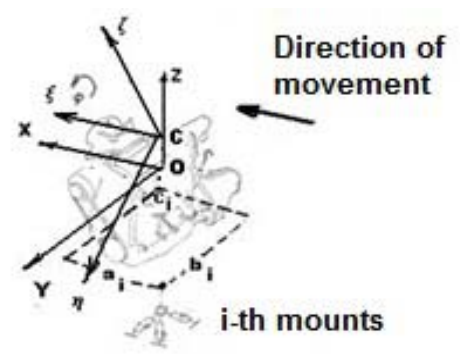

Figure 2 - Introduced coordinate systems to describe the movement of the powertrain Puc. 2 - Внедрены системы координат для описания движения силового привода Слика - 2 Уведени координатни системи за описивање кретања погонске групе

Since the aim of the research is to determine the thermal loads of the powertrain mounts, it was considered necessary to analyze only the bouncing and rolling of the powertrain, and in this case the translatory movement of the powertrain gravity center in space is defined by the coordinate $Z$ and the rotation of the powertrain (as a rigid body ) around the axis $\xi$ is defined by the rolling angle $\varphi$ (these generalized coordinates create the conditions to include the vertical exitation from the vehicle frame and the resulting inertial force, as well as the engine torque into the analysis, while respecting the recommendation to apply as simple mathematical models as possible). The elastic-viscous forces perform mechanical work in the mounts (which is converted into heat energy) due to the relative movement of the powertrain relative to the vehicle frame (deformation of the mounts). The adopted mathematical model enables the analysis of the influence of the powertrain mounts on their thermal loads. 


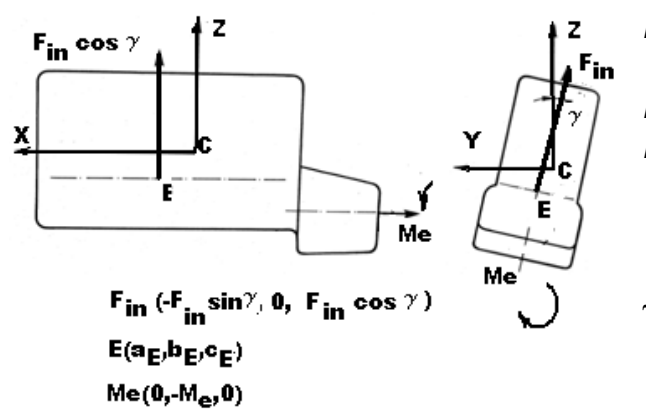

$F_{\text {in }}-$ the resulting inertial force of the piston group

$M_{\mathrm{e}}$ - engine torque

$E$ - an attack point of the resulting inertial force and its coordinates in relation to the moving coordinate system

$\gamma$ - the angle of installation of the powertrain (in this case it is $0^{\circ}$ )

Figure 3 - Excitation due to inertia force and engine torque

Рис. 3 - Возбуждение от инерционной силы и крутящего момента двигателя

Слика 3 - Побуде од инерцијалне силе и обртног момента мотора

Bearing in mind the above and using the Newton-Euler principle, differential equations can be written to describe the observed oscillatory movements of the powertrain in the form:

$$
\begin{aligned}
& M \cdot \ddot{Z}_{C}=\sum Z_{i}, \\
& I_{u} \cdot \ddot{\varphi}=\sum M_{F}{ }^{u} .
\end{aligned}
$$

In the literature (Igami et al, 2008), (Kennings et al, 2014), (Shanguan et al, 2016), (Simić \& Demić, 1992) there are a large number of mathematical models of powertrain mounts, more or less complex. Since the goal of this paper was to compare the thermal loads of the mounts, it was considered necessary to simplify the expressions for the approximation of force in the mounts (for the projections in the direction of $\mathrm{X}, \mathrm{Y}$ and $\mathrm{Z}$ axes). As far as reactive forces are concerned, they are opposed to movement.

The forces in elastic mounts are assumed in the form (Demić, 1990):

$$
F_{c i}=c_{i 1} \cdot \Delta_{i}+c_{i 2} \cdot \Delta^{2}+c_{i 3} \cdot \Delta^{3},
$$

where $c_{\mathrm{i}}, c_{\mathrm{i} 1}, c_{\mathrm{i} 2}$, and $c_{\mathrm{i} 3}$ are the stiffness coefficients, and $\Delta$ is the relative deformation of the mount. 1990):

The viscous forces in the mounts are assumed in the form (Demić,

$$
F_{a i}=k_{i 1} \cdot \dot{\Delta}+k_{i 2} \cdot \dot{\Delta}^{2} \cdot \operatorname{sign}(\dot{\Delta}),
$$

where $k_{1}, k_{2}$ are the damping coefficients, the relative deformation speed of the mount, and sign the corresponding mathematical function. 
The deformation and deformation projections of the powertrain mount in the $\mathrm{Z}$ direction are defined by the terms (Figure 2):

$$
\begin{aligned}
& \Delta Z_{i}=Z-Z_{O}-b_{i}\left(\varphi-\varphi_{O}\right), \\
& \dot{\Delta} Z_{i}=\dot{Z}-\dot{Z}_{O}-b_{i}\left(\dot{\varphi}-\dot{\varphi}_{O}\right) .
\end{aligned}
$$

The vibrations of the powertrain also depend on the unbalance of the engine (torque and inertial forces).

In this particular case, a four-stroke four-cylinder regular diesel engine with a crankshaft, whose knees were at the same level (angle $180^{\circ}$ ), was used. The piston mechanisms present forces (Mihalec et al, 2015), which are driven by a piston (the forces of gases and the inertial forces of the piston group), and on the movable bearing of the crankshaft of the centrifugal and tangential force of the crankshaft. In balancing the inertial forces of the mass of the piston group (ideally, if the force develops into the Fourier series), there remain unbalanced inertial forces of the second and higher orders. It is noted that when there are differences in the masses of piston groups per cylinders, unbalanced first-order forces occur (in this case, the case where the masses have been equal to each other).

Assuming that high-order harmonics can be neglected, the unbalanced inertial force of the observed engine can be expressed in the form (Frolov \& Furman, 1990), (Milliken \& Milliken, 1995), (Rotenberg, 1972), (Genta, 2003), (Simić, 1988):

$$
F_{i n}=4 m_{r} \cdot \omega^{2} \cdot \lambda \cdot \cos 2 \omega t
$$

where $m_{\mathrm{r}}$ is the reduced mass of the piston group, $r$ is the radius of the crankshaft knee, $\omega$ is the angular speed of the engine crankshaft, $\lambda$ is the ratio of the radius of the crankshaft and the length of the piston engine, and $t$ is time.

Based on elementary knowledge from the vector theory, statics, and Figures 2 and 3, the moment from the resulting inertial force defined by term (8) (Demić, 1990) is:

$$
\vec{M}_{F i n}=\left[\begin{array}{lrc}
\overrightarrow{u_{0}} & \overrightarrow{v_{0}} & \overrightarrow{w_{0}} \\
a_{E} & b_{E} & c_{E} \\
-F_{i n} \sin \gamma & 0 & F_{i n} \cos \gamma
\end{array}\right],
$$

where the expressions in (9) are in accordance with Figure 3.

Centrifugal forces are partially counterbalanced by counter-strategies, or by other methods, for which readers are referred to (Mahalec et al, 2015). 
The tangential force causes the torque of the engine, which due to its change has a variable value (unevenness is partially reduced by the flywheel) (Mahalec et al, 2015).

In the absence of precise data, we assume that the torque that affects the powertrain can be described by the term (Demić, 1990):

$$
M=-M_{e} \cdot i_{0} \cdot i_{m}(0,95+0,1 \cdot r n d),
$$

where $M_{\mathrm{e}}$ is the engine torque, and $i_{0}$ is the transmission ratio in the differential, $i_{\mathrm{m}}$ is the transmission ratio in the transmission, and $r$ r random numbers are evenly distributed in the interval $[0,1]$.

The vibrations of the powertrain are also influenced by the vibrations of the vehicle frame, which are incidental (Demić, 1997a), (Demić, 1997b), (Shanguan et al, 2016). Since the complexity of the vehicle spatial model exceeds the scope of this paper, it was considered appropriate not to use frame excitations obtained based on a model but to adopt broadband functions of the exitation in the following form:

$$
\text { exitation }=\max (r n d-0.5) \text {, }
$$

where $\max =0.01 \mathrm{~m}$, is work, and $r n d$ has the same meaning as with the torque of the engine.

The projections of the generalized forces include all the components of the force and momentum of the corresponding mounts in the direction of the observed axis (for mounts 1 to 4), the inertial forces and torque moments of the engine, or the unbalanced inertial forces, as well as the force of the active suspension which, due to the assumption that it operates at the powertrain center, has no moment.

\section{Heat loads of the powertrain mounts}

Due to the relative movement of the powertrain and the vehicle frame, work is carried out in the mounts, which is equivalent to the amount of heat Q (Bojić, 2011), (llić et al, 1996), (Moran, 2010), (Fermi, 2011), (Demić, 2001), (Demić, 2013), (Demić \& Diligenski, 2016), (Mitschke \& Wallentowitz, 2004). Mechanical work in mounts is defined by the expression (Mitschke \& Wallentowitz, 2004):

$$
A=\int_{0}^{s} F_{m} \cdot d z_{r e l}=\int_{0}^{T} F_{m} \cdot Z_{r e l} \cdot d t
$$


where $F_{\mathrm{m}}$ is the elasto-damping force in the mount, $z_{\text {rel }}, Z_{\text {rel }}$ is the relative deformation and the deformation rate of the mount (respectively), and $t$ is the time of deformation.

The mean mechanical strength is given by the expression:

$$
P=\frac{A}{T}=\frac{k}{T} \int_{0}^{T} z_{r e l} \cdot d t
$$

As the effective value of the relative deformation speed of the mount is:

$$
\dot{Z}_{\text {relef }}{ }^{2}=\frac{1}{T} \int_{0}^{T} \dot{Z}_{\text {rel }} \cdot d t .
$$

then the mean strength can be written in the form:

$$
P=k \cdot \dot{Z}_{\text {relef }}^{2} \text {. }
$$

It turns into heat, with dominant convection:

$$
P=\alpha \cdot S \cdot \Delta \tau,
$$

where $P$ is the power (heat flux), W; $\alpha$ is the coefficient of heat transfer, $\mathrm{W} /\left(\mathrm{m}^{2} \cdot{ }^{\circ} \mathrm{C}\right) ; S$ is the convection surface in $\mathrm{m}^{2}$; and $\Delta \tau$ is the temperature difference between the mounts and the ambient air in ${ }^{\circ} \mathrm{C}$.

Since $\alpha$ and $S$ are of unknown values and require very complicated research in order to be defined, they are not discussed in this paper.

Bearing in mind that all four mounts had the same characteristics, we considered appropriate to carry out an analysis of total heat loads.

\section{Numerical simulation and analysis of results}

From expressions (2-11), it can be established that the differential equations are non-linear and of second order. Since the Runge-Kutta method requires them to be reduced to differential equations of the first order before solving them, they are transformed into this form. In differential equations 20 parameters were used to describe the characteristics of the mounts, two inertial parameters, three parameters describing translatory motion and three parameters describing angular motion (movement, velocity, acceleration), 12 coordinates of the mounts and three coordinates of the attack point of the resulting inertial force. Differential equations were solved using the software that Demić, M. had developed in Pascal. The integration was performed with a time step of $0.0001 \mathrm{~s}$ at 524288 points. This enabled a reliable analysis in the range 
$0.019-5000 \mathrm{~Hz}$. Obviously, this range is considerably broader than the exitation range of engine motions and the complete powertrain of vehicles. The integration of differential equations was performed for the case of classical and hydraulic mounts.

The parameters of the vehicle and its powertrain are given in Table 1, and the coordinates of the connecting points (mounts) in Table 2 (FAP, 2017).

The mechanical and hydraulic mounts had identical stiffness values in the direction of the $X, Y$ and $Z$ axes, which were determined in FAP (FAP, 2017), and shown in Table 3.

Table 1 - Typical parameters of FAP1314 and its powertrain Таблица 1 - Типичные параметры ФАП1314 и его силового привода Табела 1 - Карактеристични параметри возила ФАП1314 и његове погонске групе

\begin{tabular}{|l|l|}
\hline Maximum engine power, $\mathrm{kW}$ & 100 \\
\hline Maximum engine speed, $\mathrm{min}^{-1}$ & 2600 \\
\hline Maximum engine torque, $\mathrm{Nm}$ & 428 \\
\hline Speed at maximum torque, $\mathrm{min}^{-1}$ & 1300 \\
\hline Vehicle mass, $\mathrm{kg}$ & 12000 \\
\hline Mass of the powertrain, $\mathrm{kg}$ & 1680 \\
\hline Moments of inertia $\mathrm{I}_{x} / \mathrm{I}_{\mathrm{y}} / \mathrm{I}_{\mathrm{z}}, \mathrm{kgm}^{2}$ & $85 / 35 / 72$ \\
\hline Transmission ratio in the main gearbox, - & 3.83 \\
\hline Transmission ratio in direct transmission, - & 1 \\
\hline
\end{tabular}

Table 2 - The coordinates of the connection points of mounts Таблица 2 - Координаты точек соединения опоры Табела 2 - Координате везних тачака ослонаца

\begin{tabular}{|l|l|l|l|}
\hline Position of mounts $\rightarrow$ & $a, \mathrm{~m}$ & $b, \mathrm{~m}$ & $c, \mathrm{~m}$ \\
\hline Mount 1 & 0.5 & 0.4 & 0.1 \\
\hline Mount2 & 0.5 & -0.4 & 0.1 \\
\hline Mount3 & -0.5 & 0.4 & 0.1 \\
\hline Mount4 & -0.5 & -0.4 & 0.1 \\
\hline
\end{tabular}

Table 3 - Stiffness of the used conventional and hydraulic mounts

Таблица 3 - Жесткость используемых стандартных и гидравлических опор Табела 3 - Крутости коришћених класичних и хидрауличких ослонаца

\begin{tabular}{|l|l|l|l|}
\hline & $c_{\mathrm{i} 1} \mathrm{~N} / \mathrm{m}$ & $c_{\mathrm{i} 2}, \mathrm{~N} / \mathrm{m}^{2}$ & $c_{\mathrm{i} 3,} \mathrm{~N} / \mathrm{m}^{3}$ \\
\hline$X$ & 1200000 & 250000 & 60000 \\
\hline$Y$ & 1200000 & 250000 & 60000 \\
\hline$Z$ & 1200000 & 250000 & 60000 \\
\hline
\end{tabular}


In the absence of more precise data, the damping characteristics of the mounts are approximately defined based on the stiffness of the mounts and the weight they carry (Genta, 2003), (Simić, 1988), and given in Table 4.

Table 4 - Assumed damping characteristics of the mounts

Таблица 4 - Предполагаемые демпфирующие характеристики опоры Табела 4 - Претпостављене пригушне карактеристике ослонаца

\begin{tabular}{|l|l|l|}
\hline & $k_{\mathrm{i} 1}$ (mechanical/hydraulic), Ns/m & $k_{\mathrm{i} 2}$ (mechanical/hydraulic), $\mathrm{Ns}^{2} / \mathrm{m}^{2}$ \\
\hline $\mathrm{X}$ & $620 / 62000$ & $1 / 100$ \\
\hline $\mathrm{Y}$ & $620 / 62000$ & $1 / 100$ \\
\hline $\mathrm{Z}$ & $620 / 62000$ & $1 / 100$ \\
\hline
\end{tabular}

For the sake of illustration, the vertical oscillatory exitations of the powertrain derived from the frame exitations are shown in Figure 4. It is obvious that the exitations are time-varying and high thermal loads of the powertrain mounts are to be expected. A similar commentary also applies when it comes to frame rolling exitations that are not shown here.

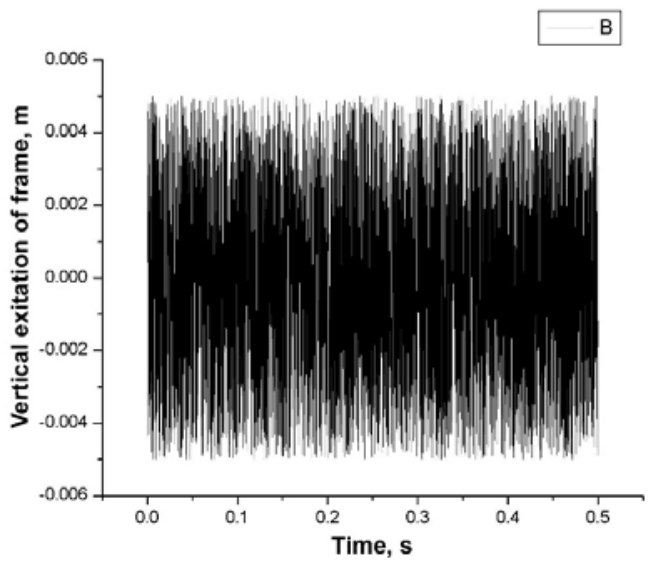

Figure 4- Illustration of the vertical excitations of the frame Puс. 4 - Иллюстрация вертикального возбуждения рамы Слика 4 - Илустрација вертикалних побуда оквира

The total heat loads of the four-point system possessing elastic and damping properties (for all components of force and momentum) are calculated using expressions (2-15), and the results are shown in Figure 5, where the values for the heat amount are given in the logarithmic proportions.

By analyzing the numerical data and Figure 5, it can be found that the mechanical mounts suffer about 49 times less thermal load than the hydraulic ones (for a time period of $52 \mathrm{~s}$, the classical is about $4.85 \times 108 \mathrm{~J}$, and the hydraulic one is $2.37 \times 1010 \mathrm{~J}$ ). This is understandable if one takes 
into account that the hydraulic mount, in addition to the hysteresis in the tire, also has additional movement of the fluid within the mounts. Figure 5 shows that the amount of heat grows over time, and that, if thermal energy were not conducted from the mounts, they would face distortion of the shape and characteristics.

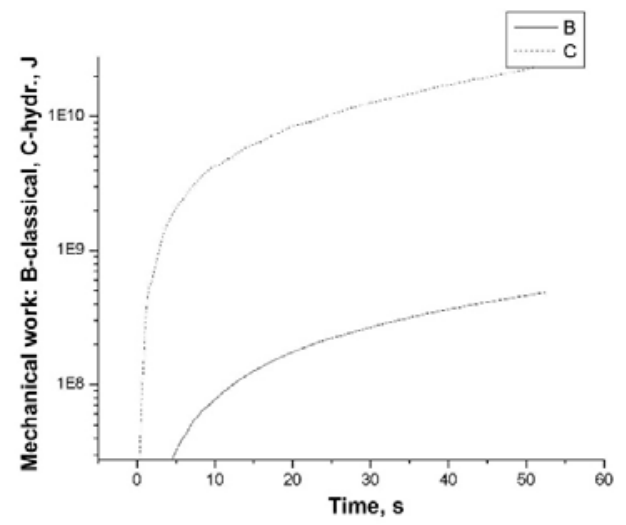

Figure 5 - Heat amount (mechanical energy) depending on the type of mounts Puc. 5 - Количество тепла (механическойэнергии) в зависимости от типа опоры Слика 5 - Промена количине топлоте (механичког рада) у ослонцима, зависно од типа ослонаца

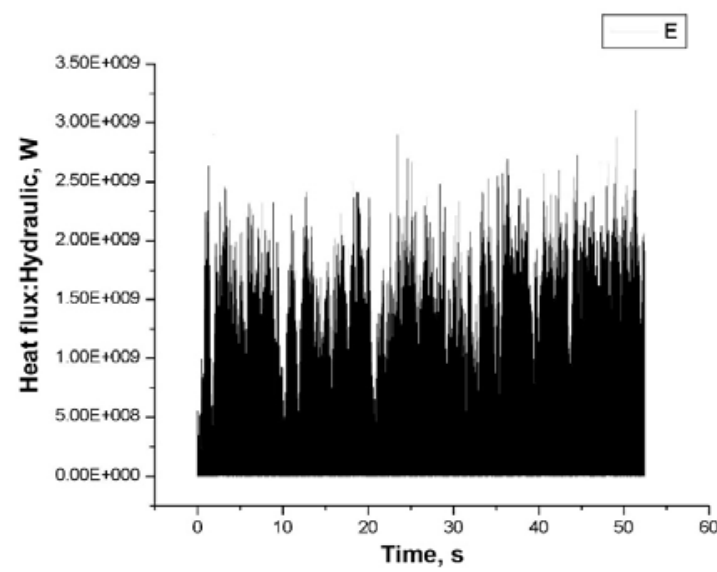

Figure 6 - The heat flux for hydraulic mounts

Puc. 6 - Тепловой поток для гидравлических опор

Слика 6 - Промена топлотног фрлукса код хидрауличких ослонаца

As noted, the heat flux for both types of mounts is calculated, and the flux for the hydraulic mounts is shown in Figure 6 for illustration. It is 
obvious that it changes stochastically with time, so it is useful to calculate the effective values for both types of mounts, given in Table 5.

Table 5 - Statistical data on heat flux

Таблица 5 - Cтатистические данные о тепловом потоке

Табела 5 - Статистички подаци о топлотном фрлуксу

\begin{tabular}{|l|l|}
\hline Mounts & Effective value of heat flux, W \\
\hline Classic & $8.26110^{6}$ \\
\hline Hydraulic & $3.63910^{8}$ \\
\hline
\end{tabular}

The analysis of the data in Table 5 indicates that the heat flux is much higher in hydraulic mounts than in the conventional (rubber-metal) mounts of the powertrain. This indicates a higher possibility of disrupting the characteristics of hydraulic mounts than those of conventional ones. That is why they are larger than the classic ones. It points to the fact that such high values are the product of rigorous exitations from the vehicle frame used in the simulation. In practice, they are significantly lower and so are the actual heat loads of the powertrain mounts. However, the research carried out aimed to determine the ratio of the thermal loads of classic and hydraulic mounts, with the help of models, so the results can be adopted as orientational, which is acceptable in the freight vehicle design phase. It should be noted that the amplitudes of vibrations of the powertrains in the case of hydraulic mounts are significantly lower than in the case of conventional mounts (Demić, 1990), (Simić \& Demić, 1992), (FAP, 2017).

As the aim of the research was to determine which component of the exitation (including the exitation forces of the inertial force and the torque of the engine) had the greatest impact on the thermal loads of the powertrain mount, it was judged appropriate to clarify this problem further on. It is known that a dynamic system with multiple input quantities and one output quantity can be shown as in Figure 7 . If there is a connection between the input quantities, the system must first be decoupled (Bendat \& Piersol, 1993), (Bendat \& Piersol, 2010). As the oscillatory model of the powertrain had 4 oscillatory exitations (2 shifts and two exitations from resulting inertial forces and the torque of the engine), we will summarize the theory that enables the analysis of the influence of each individual exitation on the thermal load of the powertrain mounts, heat fluxin particular. Figure 8 shows the distribution pattern (Bendat \& Piersol, 1993), (Bendat \& Piersol, 2010). 


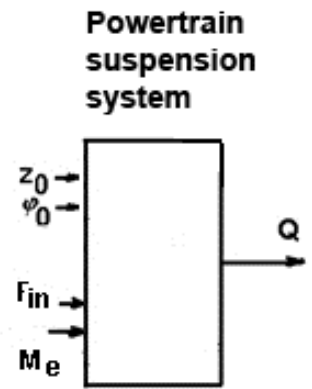

$Q$ - amount of heat or heat flux,

$Z_{0}-$ vertical exitation from the vehicle frame $(x 1)$,

$\varphi_{0}-$ exitation from rolling the vehicle frame (x2),

Fin - second-order inertial force $(x 3)$,

$\mathrm{Me}$ - engine torque $(x 4)$

Figure 7 - Block diagram of the suspension system of the powertrain

Puc. 7 - Блок-схема системы подвески силового агрегата

Слика 7 - Блок-дијаграм система за ослањање погонске групе

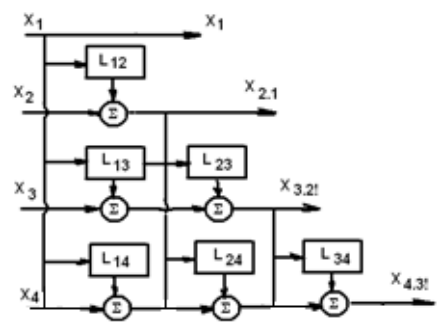

Figure 8 - Decoupling scheme

Puc. 8 - Развязывающая схема

Слика 8 - Шема распрезања

Bearing in mind the theory from (Demić, 1990), (Bendat \& Piersol, 1993), (Bendat \& Piersol, 2010) and Figure 8, it can be written (all quantities are given in the complex plane-Fourier or Laplace transformation):

$$
\begin{gathered}
x_{1 !}=x_{1}, \\
x_{2 \cdot 1 !}=x_{1}-L_{12} \cdot x_{1}, \\
x_{3 \cdot 2 !}=x_{3}-L_{13} \cdot x_{1}-L_{23} \cdot x_{2 \cdot 1 !}, \\
x_{4 \cdot 3 !}=x_{4}-L_{1 \cdot 4} \cdot x_{1}-I_{2 \cdot 1} \cdot x_{2 \cdot 4 !}-L_{3 \cdot 4} \cdot x_{3 \cdot 2 !}
\end{gathered}
$$

where $x_{1}, x_{2}, x_{3}, x_{4}$ are the input quantities,

$x_{2 \cdot 1 !}, x_{3 \cdot 2 !}, x_{4 \cdot 3 !}$-second conditional input with the eliminated influence of the first input; the third conditional input with the elimination effect of the 
first and second conditional inputs; the fourth conditional input with the elimination of the influence of the first and the conditional second and the third conditional inputs, respectively. follows:

The transfer functions between the input ports can be displayed as

$$
\begin{gathered}
L_{12}=\frac{x_{2}}{x_{1}} \quad L_{13}=\frac{x_{3}}{x_{1}} \quad L_{14}=\frac{x_{4}}{x_{1}}, \\
L_{23}=\frac{x_{3 \cdot 2 !}}{x_{2 \cdot 1 !}} \quad L_{24}=\frac{x_{4 \cdot 3 !}}{x_{2 \cdot 1 !}}
\end{gathered}
$$

where $L_{12}, L_{13}, L_{14}, L_{23}, L_{24}$ are the corresponding transfer functions between the conditional input quantities.

Note that portable functions indicate how much the output quantity is increased or decreased in relation to the input quantity and how big is the phase delay between them.

On the basis of expressions (17) and (18), partial coherence functions can be calculated, and they indicate the coupling between the input and output signals (Demić, 1990), (Bendat, 1998), (Bendat \& Piersol, 1993), (Bendat \& Piersol, 2010).

$$
\gamma_{i Q(i 1) !}^{2}=\frac{\left[S_{i Q(i-1) !}\right]^{2}}{S_{x x(i-1) !} S_{Q Q(i-1) !}},
$$

where $S_{\mathrm{QQ}(\mathrm{i}-1) !}$ is the cross-spectra (the power cross-spectra is a complex quantity that represents the boundary value of the mathematical expectation of the products of the conjugated-complex amplitude of one signal and the complex amplitude of the second signal - it enables the analysis of the spectral content of the interdependencies of the two signals) and $S_{\mathrm{xx}(\mathrm{i}-1) !}$ and $S_{\mathrm{QQ}(\mathrm{i}-1) !}$ are the corresponding autospectra (the power autospectrum is a real quantity that makes the limit value of the mathematical expectation of the products of the conjugated-complex and complex amplitude of the observed signal- it enables the analysis of the spectral content of a single signal). The function of ordinary coherence shows whether there is a connection between the input and output quantities of the system, and the partial coherence functions are used to analyze the interconnections of the input and output quantities in the case when there is a connection between the input quantities (Demić, 2001), (Bendat \& Piersol, 1993), (Bendat \& Piersol, 2010). 


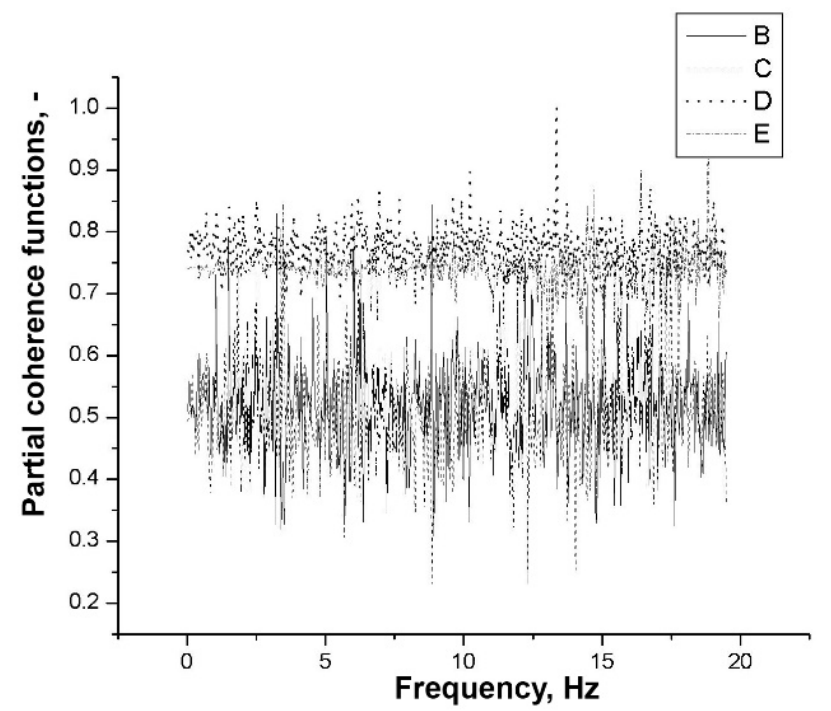

Figure 9 - Partial coherence functions for hydraulic mounts: B-vertical excitation from the frame, $C$-excitation from the rolling of the frame with excluded influence of the vertical excitation, $D$-inertial force with excluded influence of the vertical excitation and rolling of the vehicle frame and E-motor torque with excluded influence of vertical excitation and rolling of the vehicle frame and the inertial forces of the engine

Puс. 9 - Частичные функции когерентности гидравлических опор:

B-вертикальное возбуждение от рамы, С-возбуждение от качения рамы без возможности влияния вертикального возбуждения, $D$-инерционная сила без возможности влияния вертикального возбуждения и качения рамы транспортного средства и Е- момент двигателя без возможности влияния вертикального возбуждения и качения рамы транспортного средства и сил инерции двигателя

Слика 9 - Парцијалне функције кохеренци за хидрауличке ослонце: В - вертикалне побуде од оквира, C - побуда од ваљања оквира са искљученим утицајем вертикалних побуда, $D$ - инерцијална сила са искљученим утицајем побуда од вертикалних и ваљања оквира возила и E - момент мотора са искљученим утицајем вертикалних побуда и ваљања оквира возила и инерцијалне силе мотора

For a more detailed analysis, the partial coherence functions (expression 19) are calculated using the programs developed by the author in Pascal (Demić, 2001). For the illustration purposes, Figure 9 shows the calculated values for hydraulic mounts. The data analysis for the mechanical hydraulic mounts shown in Figure 9 shows that the coherent partial functions depend on the frequency and type of exitations. It is considered appropriate to carry out a more detailed analysis of the data of the partial coherence functions. In that sense, the minimum and maximum values of the coherent partial functions are calculated and given in Tables 6 and 7. 
Table 6-Minimum and maximum values of the partial coherence functions for mechanical mounts Таблица 6 -Минимальные и максимальные значения парциальных фрункций когерентности для механических опор

Табела 6 - Минималне и максималне вредности парцијалних фрункција кохеренци за механичке ослоние

\begin{tabular}{|l|l|l|}
\hline & $\min$ & $\max$ \\
\hline B & 0.308 & 0.843 \\
\hline C & 0.230 & 0.869 \\
\hline D & 0.661 & 1.000 \\
\hline E & 0.541 & 0.956 \\
\hline
\end{tabular}

Table 7 - Minimum and maximum values of the partial coherence functions for hydraulic mounts Таблица 7 - Минимальные и максимальные значения парциальных функций когерентности для гидравлических опор

Табела 7 - Минималне и максималне вредности парцијалних фрункција кохеренци за хидрауличке ослонце

\begin{tabular}{|l|l|l|}
\hline & $\min$ & $\max$ \\
\hline B & 0.252 & 0.741 \\
\hline C & 0.216 & 0.897 \\
\hline D & 0.721 & 1.000 \\
\hline E & 0.600 & 0.839 \\
\hline
\end{tabular}

The analysis of the data from the given tables shows that the type of mounts has an effect on the partial coherence functions, and that their values are in the interval of 0.216 to 1 , indicating that there is a connection between the input quantities (the exitation from the vehicle frame and the resulting inertial force and the engine torque) and heat flux (Bendat \& Piersol, 1993), (Bendat \& Piersol, 2010). The resulting inertial force and the engine torque have a greater impact on the thermal loads of the powertrain mounts.

The realized research was aimed at determining the relation between the thermal loads of the classical (rubber-metal) mounts and hydraulic mounts, with the help of a model, so that the obtained results can be adopted as a guide, which is necessary during the design phase of the conceptual design of a freight motor vehicle. It should be noted that hydraulic mounts have significantly better powertrain vibration damping parameters than the classical ones (Demić, 1990), (Simić \& Demić, 1992).

\section{Conclusion}

Based on the research carried out, it can be concluded that with the help of mechanical models, the influence of the characteristics of the powertrain mounts on their thermal loads can be analyzed. The analyzes 
have shown that hydraulic mounts are more thermally loaded than the conventional ones. Due to their heat loads and a complex construction, it is understandable why they are more rarely applied in freight motor vehicles. In order to verify the results, experimental research should also be carried out.

\section{References}

Atkins, P., 2010. The laws of thermodynamics: A very short introduction.OUP Oxford.

Bendat, J.S., 1998. Nonlinear Systems-Techniques and Applications.London: Wiley.

Bendat, J.S., \& Piersol, A.G., 1993. Engineering applications of correlation and spectral analysis.New York: Wiley-Interscience.

Bendat, J.S., \& Piersol, A.G., 2010. Random Data: Analysis and measurement procedures.London: John Wiley and Sons.

Bojić, M., 2011. Termodinamika.Kragujevac: University of Kragujevac Faculty of Mechanical Engineering (in Serbian).

Demić, M., 1990. A contribution to the optimization of the position and the characteristics of passenger car powertrain mounts. International Journal of Vehicle Design, 11(1), pp.87-103.

Demić, M., 1997a. Identification of vibration parameters for motor vehicles. Vehicle System Dynamics, 27(2), pp.65-88. Available at:http://dx.doi.org/10.1080/00423119708969323.

Demić, M., 1997b. Optimizacija oscilatornih sistema motornih vozila.Kragujevac: University of Kragujevac - Faculty of Mechanical Engineering, monograph (in Serbian).

Demić, M., 2001. Computer programs "Demparkoh", "Analsigdem".

Demić, M., 2002. Neki aspekti istraživanja „lepršanja" upravljačkih točkova teretnog motornog vozila. Vojnotehnički glasnik/Military Technical Courier, 50(3), pp.300-308. Available at: http://dx.doi.org/10.5937/vojtehg0203300D (in Serbian).

Demić, M.D., 2013. Prilog istraživanju toplotnog opterećenja amortizera poluaktivnog sistema oslanjanja motornog vozila. Vojnotehnički glasnik/Military Technical Courier, 61(3), pp.26-50. Available at: http://dx.doi.org/10.5937/vojtehg61-3572 (in Serbian).

Demić, M.D., \& Diligenski, Đ.M., 2016. Numerical simulation of shock absorbers heat load for semi-active suspension system. Thermal Science, 20(5), pp.1725-1739. Available at: http://dx.doi.org/10.2298/TSCI150624005D.

- FAP, 2017.FAP Informacije. Priboj: FAP (in Serbian).

Fermi, E., 2011. Thermodynamics.New York: Dover Books on Physics.

Frolov, K.V., \& Furman, F.A., 1990. Applied theory of vibration protection systems.Moscow: Mashinostroenie. 
Genta, G., 2003. Motor Vehicle Dynamics.Singapore: World Scientific Publishing Company.

Gillespie, T.D., 1992. Fundamentals of Vehicle Dynamics.Warrendale, PA: Society of Automotive Engineers.

Igami, H., Thompson, M., \& Osodo, K., 2008. Automotive Powertrain Mounting System Design Optimization. SAE Technical Paper, 2008-01-0879. Available at: http://dx.doi.org/10.4271/2008-01-0879.

Ilić, G., Radojković, N. \& Stojanović, I., 1996. Termodinamika II - Osnove prostiranja toplote.Niš: University of Niš - Faculty of Mechanical Engineering (in Serbian).

Kennings, P., Layfield, J., Tarabra, M., Fothergill, D., Syred, F., \& Franks, G., 2014. Developing Powertrain Mounting Systems in the Virtual Engineering World Using a Full Vehicle NVH Simulator. In: INTER-NOISE and NOISE-CON Congress and Conference Proceedings, Melbourne, Australia, pp.2263-2272.

Mahalec, I., Kozarac, D. \& Lulić, Z., 2015. Konstrukcije motora.Zagreb: FSB (in Serbian).

Milliken, W.F., \& Milliken, D.L., 1995. Race Car Dynamics.Warrendale, Pennsylvania: Society of Automotive Engineers.

Mitschke, M., \& Wallentowitz, H., 2004. Dynamik der Kraftfahrzeuge.Berlin - Heidelberg: Springer (in German).

Moran, M.J., \& et al, 2010. Fundamentals of Engineering Thermodynamics. Hoboken: John Wiley and Sons.

Pars, L.A., 1981. A Treatise on Analytical Dynamics.Oxford: Ox Bow Press.

Rotenberg, R., 1972. Podveska avtomobilja. Moscow: Mashinostroenie (in Russian).

Shanguan, W.B., \& et al, 2016. Design method of automotive powertrain mounting system based on vibration and noise limitations of vehicle level. Mechanical Systems and Signal Processing, 76, pp.677-695. Available at: http://dx.doi.org/10.1016/j.ymssp.2016.01.009.

Simić, D., 1988. Dinamika motornih vozila.Belgrade: Naučna knjiga (in Serbian).

Simić, D., \& Demić, M., 1990. Elastično oslanjanje pogonske grupe. In: Kragujevac: MVM, monograph (in Serbian).

\section{ПРИЛОЖЕНИЕ К ИССЛЕДОВАНИЮ ТЕПЛОВОЙ НАГРУЗКИОПОРЫ СИЛОВОГО ПРИВОДА ГРУЗОВОГО АВТОМОБИЛЯ}

Мирослав Д. Демич, Ясна Д. Глишович

Университет г. Крагуевац, Инженерный факультет,

Департамент автотранспортных средств и двигателей, г. Крагуевац,

Республика Сербия 
ОБЛАСТЬ: машиностроение, автомобили и двигатели

ВИД СТАТЬИ: оригинальная научная статья

ЯЗЫК СТАТЬИ: английский

Резюме:

Под действием возбуждений, возникающих в результате микрошероховатости дорог, трансмиссии, а также условий движения (ускорение, торможение, криволинейное движение), массы коммерческих транспортных средств совершают сложные колебательные движения. Негативное воздействие этих перемещений, а соответственно и динамических нагрузок на опорную систему транспортного средства, может быть снижено при соответствующем выборе положения и характеристик опоры силового агрегата. Как показывает практика, при согласовании характеристик опоры силового привода чаще всего учитываются такие фракторы, как минимальный шум и вибрации транспортного средства, в то время как проблеме тепловых нагрузок, которым они подвергаются при эксплуатации, практически не уделяется никакого внимания. Необходимо учитывать тот фракт, что повышенные тепловые нагрузки неизбежно приводят к повреждению опоры и ухудшению ее характеристик. Следует отметить, что силы упруго-демпферных опор выполняют механическую работу, преобразуя механическую энергию в тепловую. Анализ тепловых нагрузок на опоры может быть выполнен с помощью теоретических, экспериментальных и комбинированных методов. В настоящей работе представлены результаты исследования, полученные на основании теоретических методов и упрощенной механической модели трансмиссии. В ходе исследования испытаны вибрации силового привода грузового автомобиля среднего класса производственной линейки ФАП 1314. С учетом того, что современные грузовые автомобили оснащены как стандартными механическими, так и гидравлическими опорами был проведен анализ тепловой нагрузки с помощью математического моделирования, применяемого в обоих случаях. Исследования проведены с целью определения соотношения тепловой нагрузки стандартных механических и гидравлических опор с помошью математических моделей, таким образом, полученные результаты могут считаться ориентировочными, что является важным фрактором на этапе проектирования коммерческого автотранспортного средства. Анализ показал, что количество тепла, вырабатываемого при применении гидравлических опор, значительно выше, чем в случае применения стандартных механических опор. Кроме того, расчет парциальных функций когерентности теплового потока показал, что их значения находятся в диапазоне от 0,216 до 1, что указывает на взаимозависимость между входными значениями и тепловым потоком. Кроме того, доказано, что инерционная сила и крутящий момент

\section{1}


оказывают большее влияние на тепловую нагрузку силовых агрегатов, чем вибрационное возбуждение рамы транспортного средства.

Ключевые слова: возбуждение, коммерческий автотранспорт, опоры, моделирование, силовой привод, теплота.

\section{ПРИЛОГ ИСТРАЖИВАЊУ ТОПЛОТНИХ ОПТЕРЕЋЕЊА ОСЛОНАЦА ПОГОНСКЕ ГРУПЕ ТЕРЕТНОГ МОТОРНОГ ВОЗИЛА}

Мирослав Д. Демић, Јасна Д. Глишовић

Универзитет у Крагујевцу, Факултет инжењерских наука, Катедра за моторна возила и моторе, Крагујевац, Република Србија

ОБЛАСТ: машинство, моторна возила и мотори ВРСТАЧЛАНКА: оригинални научни чланак ЈЕЗИКЧЛАНКА: енглескИ

\section{Сажетак:}

Под дејством побуда од микронеравнина путева, погонске групе, као и од услова кретања (убрзавање, кочење, криволинијско кретање) масе теретних возила врше сложена просторна осцилаторна кретања. Негативан утицај тих кретања, односно динамичких оптерећења које она изазивају и преносе на носећи систем возила, може се смањити правилним избором положаја и карактеристика ослонаца погонске групе.

У пракси се усаглашавање карактеристика ослонаца погонске групе, најчешће, врши из услова минималне буке и вибрација возила, при чему се, углавном, занемарују топлотна оптерећења којима су они изложени у експлоатацији, а зна се да она неминовно доводе до оштећења самих ослонаца и нарушавања њихових карактеристика.

Треба напоменути да еласто-пригушне силе у ослонцима врше механички рад који се претвара у топлотну енергију. Анализа топлотних оптерећења ослонаца може се вршити коришћењем теоретских, експерименталних и комбинованих метода. У овом раду истраживања су вршена применом теоријских метода уз коришћење упрошћеног механичког модела погонске групе. При томе су посматране вибрације погонске групе теретног моторног возила средње класе из производног програма ФАП 1314. Имајући у виду заступљеност класичних (гумено-металних) и хидрауличких ослонаца погонске групе код савремених теретних моторних возила, у раду су извршене анализе топлотних оптерећења поменутог возила, уз коришћење математичког модела.

Реализована истраживања имала су за циљ да се утврди однос топлотних оптерећења класичних и хидрауличких ослонаца, уз помоћ модела, па се добијени резултати могу усвојити као 
оријентациони, ито је неопходно у фрази израде идејног пројекта теретног моторног возила. Анализа је показала да је развијена количина топлоте код хидрауличких ослонаца вишеструко већа него у случају коришћења класичних ослонаца.

Поред тога, израчунате парцијалне функције кохеренци топлотног фрлукса су показале да су њихове вредности у интервалу 0,216 до 1, што указује на то да постоји веза између улазних величина и топлотног фрлукса. При томе, већи утицај на топлотна оптерећења ослонаца погонске групе имају инерцијална сила и обртни момент мотора него осцилаторне побуде оквира возила.

Кључне речи: побуда, комерцијална возила, ослонци, моделирање, погонска група, топлота.

Paper received on / Дата получения работы / Датум пријема чланка: 15.05.2017.

Manuscript corrections submitted on / Дата получения исправленной версии работы / Датум достављања исправки рукописа: 07.08.2017.

Paper accepted for publishingon / Дата окончательного согласования работы / Датум коначног прихватања чланка за објављивање: 09.08.2017.

(C) 2017 The Authors. Published by Vojnotehnički glasnik / Military Technical Courier (www.vtg.mod.gov.rs, втг.мо.упр.срб). This article is an open access article distributed under the terms and conditions of the Creative Commons Attribution license (http://creativecommons.org/licenses/by/3.0/rs/).

() 2017 Авторы. Опубликовано в «Военно-технический вестник / Vojnotehnički glasnik / Military Technical Courier» (www.vtg.mod.gov.rs, втг.мо.упр.срб). Данная статья в открытом доступе и распространяется в соответствии с лицензией «CreativeCommons» (http://creativecommons.org/licenses/by/3.0/rs/).

() 2017 Аутори. Објавио Војнотехнички гласник / Vojnotehnički glasnik / Military Technical Courier (www.vtg.mod.gov.rs, втг.мо.упр.срб). Ово је чланак отвореног приступа и дистрибуира се у складу са Creative Commons лиценцом (http://creativecommons.org/licenses/by/3.0/rs/). 